\title{
Ethical Antecedents of Dysfunctional Behaviour in Performance Measurement and Control System
}

\author{
Noor Liza Binti Adnan ${ }^{1}$, Che Zuriana Muhammad Jamil ${ }^{2} \&$ Nor Azila Mohd Nor $^{2}$ \\ ${ }^{1}$ Universiti Teknologi MARA, Malaysia \\ ${ }^{2}$ Universiti Utara Malaysia, Malaysia \\ Correspondence: Noor Liza Binti Adnan, Universiti Teknologi MARA, Malaysia. E-mail: \\ noorliza@tganu.uitm.edu.my
}

Received: September 27, 2012 Accepted: October 22, 2012 Online Published: December 31, 2012

doi:10.5539/ass.v9n1p29

URL: http://dx.doi.org/10.5539/ass.v9n1p29

\begin{abstract}
The importance of performance measurement and control system (PMCS) in enhancing the firm profitability and sustainability has certainly been admitted by many, but findings on its effectiveness have been inconclusive with certain dysfunctional behaviours (DB) like budgetary slack, information or measures manipulation, or gaming, have been reported. Hence, a lot has been debated about what actually lead to these DBs. However, the bulk of researches has only concentrated on the technical aspects towards the betterment of the system which is unfortunately not always true. Ironically, though ethics has captured vast attention and has been admitted as bearing great importance in influencing one's behaviour, it is a great surprise that very few empirical studies had linked ethics to DB in the context of PMCS. Hence this paper will try to propose how ethical antecedents will affect employees' propensity to engage in DB. Based on reviews of extant literatures, the article first elaborates the DB in the context of PMCS before proceeding to the ethical antecedents, grouped in personal and organizational ethics, believed to influence the occurrence of DB. Propositions on how these factors will influence DB will be discussed based on social learning theory which would lead to the proposed theoretical framework. Practical implications will also be discussed.
\end{abstract}

Keywords: dysfunctional behaviour, information manipulation, performance measurement and control system, ethical attitude, ethical ideology, ethical work climate, code of ethics, perceived ethical leadership, social learning theory

\section{Introduction}

The issue of dysfunctional behaviour (DB), specifically an unintended consequence of the implementation of performance measurement and control system (PMCS) has received much attention ever since it was raised by Argyris (1953), Ridgway (1956) and later by other authors like Hopwood (1972) and Otley (1978). Despite the interest and concern regarding this negative outcome which is also believed to affect the effectiveness of PMCS, not many researchers have embarked into the exploration to unearth the root of this problem (Soobaroyen, 2007). Though abundance of researches have been conducted towards the betterment of PMCS, this bulk of researches has solely concentrated on the technical aspects through introduction of more sophisticated performance measurement methodologies, standards and indicators (Drongelen, \& Fisscher, 2003; Vakkuri, \& Meklin, 2006), which is unfortunately not always true. The paucity of research is not surprising, though, considering the delicate nature and complexity of the issue. Gaming behaviour, metric manipulations, or management myopia are difficult to identify because it is typically hidden from the researcher (Courty, \& Marschke, 2008; Soobaroyen, 2007) and in many cases, from the organization (Courty, \& Marschke, 2008). Gaining honest responses also proves difficult (Hirst, 1983; Merchant, 1990), besides the difficulty to determine, measure and predict actual behaviour in real life (Kantor, \& Weisberg, 2002). Unfortunately, the issue remains important, hence, needs further probe and investigation.

PMCS was historically developed as a means of monitoring and maintaining organizational control for monitoring performance, identifying areas in need of attentions, enhancing motivation, improving communication and strengthening accountability (Waggoner, Neely, \& Kennerly, 1999), hence aligning people's behaviour towards continuous improvement (Martinez, 2005). However, it also has its dark side. As PMCS is expected to facilitate the monitoring of the employees' behaviour (Martinez, 2005; Nanni, Dixon, \& Vollman, 
1990; Otley, 1999; Waggoner et al., 1999), it is expected to keep 'watchful eyes' on all employees (Argyris, 1953). However, as human will become sceptical when 'watched' and measured that reflect their work efficiency and effectiveness, there is a tendency for the managers to paint a better picture of their performance evaluation reports (Argyris, 1953, 1990; Flamholtz, 1996; Jaworski, \& Young, 1992; Soobaroyen, 2007). Eventually, it would lead them to attempts of DB by "... manipulating elements of an established control system for his own purposes," (Jaworski \& Young, 1992, p.18). Somehow, Argyris (1990) and Flamholtz (1996) had anticipated such behaviours in response to any controls and process system that act as managers' defence mechanisms to cover up or disguise failures, or to avoid threats and embarrassment. Onsi (1973) discovered majority of managers, especially those of high performers, were willing to engage in DB to hedge themselves against uncertainty which could exist in both good and bad times with full cooperation from their subordinates.

Unfortunately, such practices can have very dysfunctional effects. Since top management and other managers also rely on these fabricated reports to take decisions and actions, misguided decisions could be made that would lead to wrongly allocating resources, poor products pricing, and poor investment decisions, resulting to sub-optimal performance of the whole organization (Argyris, 1990; Jaworski, \& Young, 1992; Soobaroyen, 2007). In the business world, DB, especially the manipulation of information or performance measures, has become part of acceptable practices that is even encouraged by the top management (Argyris, 1990; Flamholtz, 1996) as companies are being more pressured to report better financial positions (PricewaterhouseCoopers, 2009).

Drongelen \& Fisscher (2003) attributed these undesired consequences of PMCS to the unethical practices of the employees who are often faced with moral dilemma between doing what is right for themselves, or for the employees, or for the organization as a whole. Ethical problem is seen as so prevalent in today's business (KPMG, 2010; PricewaterhouseCoopers, 2009) as operations becoming more complex and competition keeps increasing. In their strive to ensure their periodical results compare favourably with the predicted results defined by the standard (Argyris, 1953), managers are often experiencing considerable tension in discriminating 'ethical' from 'unethical' and in translating into actions what they consider 'right', forcing them to choose between personal values and loyalties towards organizational goals (Gupta, \& Sulaiman, 1996). As such, Vakkuri and Meklin (2006) posited that designing and implementing a PMCS would require managers with higher order of cognitive moral development, which Brown and Stilwell (2005) asserted as a key focus in an effective system. This study aims to propose how ethical antecedents, categorized into personal and organizational ethics, will affect DB and which category would appear a stronger predictor. If it is so, it would seem that to have an effective PMCS, not only must the format and function of the PMCS be correct, but also ethically conducted, making PMCS and ethics two inseparable variables.

\section{Literature Review and Hypotheses Development}

\subsection{Dysfunctional Behaviour}

Dysfunctional behaviour (DB) actually originated from the seminal work of Argyris (1953) which illustrates how budget process leads to the unintended outcomes as a result of negative employees' perception associated with budget. He discovered that budgets actually affects people so directly that employees frequently perceive it as a basis for both rewarding and also penalizing. In 1956, Ridgway further proposed that this DB actual stems from the lack of understanding of motivational and behavioural consequences of PMCS that will lead to indiscriminate use, undue confidence and reliance in the system that may eventually result in side effects and reactions outweighing its benefits. Birnberg, Turopolec and Young (1983) then came up with a more elaborative account of DB in accounting. These early studies have somehow motivated others to keep exploring and developing the research issue besides introducing other variables.

Based on the definition offered by Jaworski and Young (1992, p. 18) of DB as "... actions in which a subordinate (purposefully) attempts to manipulate elements of an established control system for his own purposes", Soobaroyen (2007, p.104) summarized that DB may constitute any behaviour "but with common and underlying objectives: to use the rules and procedures to one's advantage; or with a view to avoid a potential threat to one's position/standing in the organizations". In short, Jaworski and Young (1992) asserted that a subordinate's behaviour is dysfunctional if he knowingly violates established control system rules and procedures. This behaviour may harm the organizations as it grants privileges to the managers' interest in a way that do not benefit the organization (Simons, 1995). Based on the literatures, in the context of this paper, DB is be defined as

"any voluntary acts of the employees to manipulate the elements of the performance measurement and control system so as to produce a better report, either for the benefit of the subordinates, superiors or just serving self-interest." 
There are many forms of DB that have been discussed in the literature. Among the most referred to is the classification made by Birnberg et al. (1983) who classified the DB into six broad categories, namely 'smoothing', 'biasing', 'focusing', 'gaming', 'filtering', and 'illegal act or falsification' which can be considered as too detail, making some forms of DB appear redundant. The classification was then adapted and empirically tested by Jaworski and Young (1992), resulting in only two captions, which are gaming and information manipulation, which was later adapted by Soobaroyen (2007). They defined 'gaming performance indicators' as "...chooses an action which will achieve the most favourable personal outcome regardless of the action the superior prefers" (p. 18). Fisher and Downes (2008) defined gaming as "...taking advantage of the loopholes in the rules and system under which they operate" (p. 248), which is a result of subordinates' rebel following a belief that the control system measures performance on the wrong task or only on a limited number of their required tasks. On the other hand, "Information manipulation" has been redefined as "...subordinates alter the free flow of information, report only those aspects of an information set that is in their best interest, or in the extreme, falsify data and company records" (p. 19), which includes Birnberg's et al. (1983) earlier captions of smoothing, filtering, and falsification of information. Fisher and Downes (2008) further elaborated it as presenting information in a manner that recipient is likely to form an incorrect understanding, including misclassifying things, or lying or falsifying of data. This paper will only focus on information or measures manipulation as it is the most common and prevalent, yet is being taken for granted by many (Argyris, 1990).

Several factors have been suggested in the extant literatures to trigger the DB. Among them are the properties of PMCS implemented, like a highly embedded PMCS (Lau, 1999), or an imbalanced system that emphasizes on single high priority targets (Hirst, 1981; Jaworski, \& Young, 1992; Keasey, Moon, \& Duxbury, 2000), or a PMCS employing excessive performance measures as it may become cumbersome and open to the issue of subjectivity (Keasey et al., 2000). Such PMCS will cause the employees to believe that the measures that they are assessed against is incomplete (Hirst, 1981), inaccurate (Fisher \& Downes, 2008), or only consider a limited number of their required tasks, especially the wrong tasks (Jaworski \& Young, 1992). This will cause them to lose trust in the measures and begin to rationalize that manipulating data is indeed a proper way to achieve a better performance report especially when their score is relatively low (Fisher, \& Downes, 2008).

Besides, employees in a centralized organization and lack of goal congruence are more motivated to act in dysfunction, where managers tend to report information that portrays a much worse situation so as to bolster their unit for additional resources (Fisher, \& Downes, 2008). This is further encouraged with the presence of opportunity coupled with certain incentive (Harell, \& Harrison, 1994; Wells, 2001), especially when the probability of being detected and caught, and the damaging consequences are low, and potential rewards is high (Millar, \& Millar, 1997). In addition, when an organization tolerates metric manipulation, Jaworski and Young (1992) noted such an act of an employee will trigger the same intention among his peers for fear that his performance evaluation might suffer if he goes against them. Besides, a reward system (Fisher, \& Downes, 2008; Tang, Chen, \& Sutarso, 2008) and unrealistic goals set (Schweitzer, Ordonez, \& Douma, 2004) may also result to a huge amount of pressure, leading to information manipulation. Sometimes, to avoid unwelcome attention that will invite hassle, close scrutiny or audit, employees may manipulate the measures when they either perform very well or very badly (Fisher \& Downes, 2008).

As discussed above, many factors are found to have triggered the dysfunctional acts in the PMCS, but very limited study has been linked to the ethical aspects, though it may well be viewed as an ethical issue as it involves a predicament with moral component with volitions on the part of the decision-maker and consequences for others (Douglas, \& Wier, 2000). As such, one's approach in resolving ethical questions differs. Drongelen and Fisscher (2003) emphasized that the success or failure of the PMCS actually stems from the ethical conduct of the actors of the system as they are the fundamental blocks underlying the design, implementation and use of the system. Therefore, the next section will examine the ethical antecedents that might influence the propensity to engage in DB.

\subsection{Ethical Antecedents}

If this ethical dimension could explain the downfall of Enron; or the inflated profit of $\$ 9$ billion by World-Com; or the shutting down of Authur-Anderson (Velasquez, 2006), then surely it could be powerful enough to explain an ineffective PMCS. In Malaysia, ethical problem continues to be a serious threat within corporate Malaysia with $49 \%$ of Malaysian companies surveyed experiencing at least one incident of fraud with a total loss of RM63.95 million (KPMG, 2010). However, unfortunately, ethics in relation to PMCS has not been sufficiently discussed (Brown \& Stillwell, 2005), though the whole process is filled with ambiguity and complexities that will require highly ethical managers to successfully run it (Brown, \& Stilwell, 2005; Vakkuri, \& Meklin, 2006). 
Trevino and Nelson (2004) defined 'ethics' as a set of moral principles or values, acting as "the principles, norms and standards of conduct governing an individual or group" (p. 13) and is highly personal and very relative. As such, it could have many interpretations and may mean differently to different people. Jennings (2006) described ethics as generally accepted rules of conduct that govern society which comprises of both standards and expectations for behaviour that we have developed for nearly all aspects of life. As ethics consists of unwritten rules developed to interact with others, they are actually of a higher standard and norms that are far beyond laws and legal rights.

Many researchers (like Adams, Tashchian, \& Shore, 2001; Kish-Gephart, Harrison, \& Trevino, 2010; Trevino, \& Nelson, 2004; Victor, \& Cullen, 1988) have acknowledged that ethical situations actually involve a combination of both individual and situational factors which may better explain ethical lapses than either factor alone, which is in line with the postulation made in social learning theory. Critical reviews of these two contributing variables pointed to two personal ethics, namely a person's ethical ideologies (Kish-Gephart et al., 2010), and ethical attitudes (Izraeli, 1988), and three organizational ethics constructs, namely code of ethics (Adams et al., 2001; Kish-Gephart et al., 2010), ethical work climate (Kish-Gephart et al., 2010; Victor, \& Cullen, 1988; Wimbush, Shepard, \& Markham, 1997), and perceived ethical leadership (Brown, Trevino, \& Harrison, 2005; Brown, \& Trevino, 2006). Each of these variables will be looked into in the next section.

\subsubsection{Ethical Attitude (EA)}

Under personal ethics, ethical attitudes (EA) has been suggested as the best predictor of employees' unethical behaviour (Izraeli, 1988) and has attracted a profound concern as evidenced by the large number of studies published (like Ghosh, \& Crain, 1995; Izraeli, 1988; Kantor, \& Weisberg, 2002; Longenecker, McKinney, \& Moore, 2003; Longenecker, Moore, Petty, Palich, \& McKinney, 2006; Medlin, \& Green, 2003; Reckers, Sanders, \& Roark, 1994; Wong, 2008; Zabid, \& Alsagoff, 1993). EA refers to the perceived rightness or wrongness of a situation which might reflect a favourable, unfavourable, or neutral view, and subsequently affect one's decision whether to commit a behaviour (Kantor, \& Weisberg, 2002). However, it is highly personal and relative (Longenecker et al., 2006; Trevino, \& Nelson, 2004), hence, many employees would not view information manipulation in the PMCS with the same sense of morality (Argyris, 1990; Fisher, \& Downes, 2008), with some might even view it as ethical especially if it is encouraged by management and anticipated by subordinates (Flamholtz, 1996). Hence, it makes this variable as very interesting and highly relevant in explaining the occurrence of DB.

EA is one of the fundamental cognitions formed in a human mind according to cognitive dissonance theory that plays a crucial role in influencing how an individual would behave (Rudolph, 2006). Since people would try to avoid dissonance and prefers a consonance among their cognitions (Rudolph, 2006), they would try to align their attitude and behaviour, or adjust their attitude so as to depict their behaviour. As such, it can be argued that EA will significantly influence whether or not a manager would engage in DB, or likewise, how one behaves may actually mirror their EA. Prior researchers (like Ferrell, \& Weaver, 1978; Izraeli, 1988; Kantor, \& Weisberg, 2002) suggested that employees could be more ethical in some behavioural situations than in others and different situations may lead to different ethical perceptions. Employees exhibited strong ethical attitude against the perceived most unethical actions that clearly may hurt another person or damage the organization, but were much simpler to rationalize and justified the slightly unethical acts.

In examining how EA affect ethical behaviour, researchers (Ghosh, \& Crain, 1995; Mitchelli, \& Chan, 2002; Reckers et al., 1994; Weber, \& Gillespie, 1998) discovered that a statistically-significant negative relationship did exist between the EA and behaviour. When an individual perceives an action as immoral, he/she is less likely to act upon it regardless of the situation (Ghosh, \& Crain, 1995; Reckers et al., 1994) as the ethical attitude would act as an alarm, affecting their judgment and subsequently their decision whether or not to engage in such behaviour (Weber, \& Gillespie, 1998). As such, people with strong ethical beliefs are more unlikely to engage in DB, implying that different strengths of belief may explain the correlations between attitude and behaviour (Mitchelli, \& Chan, 2002). However, considering the paradox nature of DB in the context of PMCS and no prior study has been empirically conducted to examine the relationship, the following hypothesis can be theorized:

H1: There is a relationship between managers' ethical attitudes and their propensity to engage in dysfunctional behaviour.

\subsubsection{Ethical Ideology (EI)}

As an individual enters into an organization with his own characters, his ethical ideology (EI) will impact his ethical belief and determine what they believe to be right or wrong, which will subsequently explain their moral choice and differences in ethical judgment (Barnett, Bass, \& Brown, 1994). Henle et al. (2005) defined EI as "a 
system of ethics used to make moral judgments, which offers guidelines for judging and resolving behaviour that may be ethically questionable" (p. 219). As such, given the same information, two persons who are in agreement over political or religious issue, might reach opposite conclusion regarding a moral judgment. As one proposed cognition under cognitive dissonance theory (Rudolph, 2006), personal EI has been proven to give considerable impact regarding when and how an individual decides to engage in DB (Forsyth, 1992; Henle et al., 2005). DB, like information manipulation, involves ethically questionable activities, and might sometimes be considered as a cushion in the case of a hard fall, and there might be a possibility that these kinds of behaviour can, in fact, be considered as a norm to protect the employees from unexpected events (Van der Stede, 2000), and as such, ethical. Hence, judging whether to engage in it varies as a function of a person's EI (Barnett et al., 1994; Barnett, Bass, Brown, \& Hebert, 1998; Davis, Andersen, \& Curtis, 2001; Forsyth, \& Berger, 1982; Henle et al., 2005). As such, behaviour engaged would mirror the personal EI adopted, making it a potential predictor of DB.

Reviews of literature suggested that one's EI does have an important impact on ethical sensitivity, ethical judgement and ethical behaviour. It has been discovered to have influenced deviant workplace behaviour (Henle et al., 2005), earning management (Greenfield, Norman, \& Wier, 2008), and ethical judgment and moral behaviour (Barnett et al., 1994; Bass, Barnett, \& Brown, 1998; Fernando, Dharmage, \& Almeida, 2008; Forsyth, 1992; Forsyth, \& Berger, 1982; Marques, \& Azevedo-Pereira, 2009). Majority of the findings revealed that differences in EI, along the dimension of idealism to relativism, would be significantly associated with differences in individual's ethical judgement and moral behaviour. Douglas and Wier (2000) noted that relativists were less sensitive to identify ethical tones as compared to idealists. Employees higher in relativism and lower in idealism were more likely to engage in deviant behaviour towards their organization (Barnett et al., 1998; Bruns, \& Merchant, 1990; Greenfield et al., 2008; Henle et al., 2005).

In this study, it is expected that employees higher in idealism will try to uphold the values, rules and principles in their daily pursuit, hence avoiding manipulation of information at any opportunity, as compared to a relativistic manager who would be more open to exceptions, and in exploring alternatives of actions even if standards and guidelines are readily available to guide their behaviour. Idealists are more concerned with the welfare of others, and would try to maximize the desirable outcomes of a decision by strictly following the universal moral rules and principles, in contrast to the relativists who tend to reject universal moral codes as they strongly believe that ethics should be situationally determined. Hence, they would avoid manipulating information as it might not only hurt their organization financially, but may leave negative consequences for other employees or consumers. This argument leads to the next hypotheses:

\section{H2(a): Idealism is negatively correlated with dysfunctional behaviour.}

\section{H2(b): Relativism is positively correlated with dysfunctional behaviour.}

\subsubsection{Code of Ethics (COE)}

Adams et al. (2001), Kish-Gephart et al. (2010), Wimbush, Shepard, and Markham (1997), and Victor and Cullen (1988) to name a few, found that organizations do create bad and good social environments that can influence individual's unethical behaviour. Code of ethics (COE), written and formulated at the head-quarter, can be disseminated and communicated to other branches so that all branches would adhere to the same codes and rules of conduct. However, researches on COE has shown mixed finding with little empirical knowledge and lack of solid evidence about the extent to which it actually prevents unethical behaviour in the workplace (Kaptein, 2011; Stevens, 1994). As the mere existence of the code does not necessarily amount to its effectiveness, Kaptein (2011) noted that the effectiveness of COE range from counterproductive to extremely valuable. Therefore, whether $\mathrm{COE}$ are related to the creation of more ethical managers, hence influencing their decision to engage in DB, still haunts scholars in the business ethics (Helin, \& Sandstrom, 2007).

$\mathrm{COE}$ is a written formal document of moral standards used to guide and gauge employee or corporate ethical behaviour (Schwartz, 2001), through which the employees will learn the dos and the don'ts in an organization. As postulated in the social learning theory, employees will observe the rewards obtained for obeying the rules, or the sanction imposed following the violation of the codes, which through vicarious learning, would tactfully find its way to be embedded as values adopted among members in an organization. As suggested by some researchers, (like Adams et al., 2001; Kaptein, 2011; Kish-Gephart et al., 2010; Okpara, 2003; Peterson, 2002a; Somers, 2001) a properly enforced COE can have a powerful influence on employees' ethical behaviour where respondents in organizations with formal $\mathrm{COE}$ were more aware of wrongdoing than were respondents in organizations without formal COE (Okpara, 2003; Somers, 2001). Though mixed findings have been reported, but this study will take a positive view that enactment of COE would lead to more ethical behaviour in an organization.

At the very least, the presence of the code serves as a symbolic role, indicating that management places some 
value and importance on ethical behaviour and moral consideration in its functions (Adams et al., 2001), thus providing a supportive environment that encourages ethical behaviour (Valentine, \& Barnett, 2002). Conversely, the absence will lead managers to make decisions that are ethically inconsistent and arbitrary (Helin, \& Sandstrom, 2007). This argument leads to the following hypothesis:

\section{H3: There is a negative relationship between corporate codes of ethics and managers dysfunctional behaviour.}

\subsubsection{Ethical Work Climate (EWC)}

An informal control, EWC coined by Victor and Cullen (1987, 1988), which comprised of common values, beliefs, and traditions conveyed to employees through subtle readings relayed by supervisors and co-workers, is argued as more powerful in controlling the behaviour of the employees (Falkenberg, \& Herremans, 1995). Victor and Cullen $(1988,1987)$ and Wimbush, Shepard, and Markham (1997) argued that EWC provides the cues to employees in guiding them when they are faced with certain dilemmas, and regarding what behaviours are important, appropriate, and likely to be rewarded and not rewarded, which can be perceived through the actions and attitudes of others. In this case, it may fit the postulation made in social learning theory that individuals learn of the acceptable and unacceptable behaviours through both methods, directly, via their own experience, and vicariously, through the experiences of those around them (Bandura, 1977, 1986).

Although Victor and Cullen (1987) hypothesized nine ethical climate types, many researchers found only five climate types, namely Caring, Independence, Instrumental, Law and Code, and Rules, which might differ from one organization, or sub-units, to another (Wimbush et al., 1997). From the five ethical climate types emerged, researchers (like, Martin, \& Cullen, 2006; Peterson, 2002a; Vardi, 2001; Victor, \& Cullen, 1988; Wimbush, \& Shepard, 1994; Wimbush et al., 1997) discovered that the four climates, Caring, Rule, Law and Code, and Independence, were all found to be negatively related to unethical behaviour, like stealing, or lying, and noted that the unethical behaviour decreases as the strength of the climates increase, with Caring climate emerged as the most ethical climate. Therefore, this study takes a stand that strong ethical work climates are negatively linked to DB in organizations, leading to the following hypothesis:

\section{H4(a): There is a negative relationship between the stronger ethical climate types of Caring, Rules, Law and Codes, and Independence, with the dysfunctional behaviour among the managers.}

Instrumental climate, conversely, was found to have triggered more unethical behaviour among members in the organization and was positively related to being an accomplice, fraud and outright deception as it focuses on 'getting ahead' at the expense of caring and rules (Cullen, Victor, \& Stephens, 1989; Peterson, 2002b; Wimbush, \& Shepard, 1994; Wimbush et al., 1997). In a weaker ethical climate also, higher employee misconducts were detected (Fritzsche, 2000; Mayer, Kuenzi, \& Greenbaum, 2010; Vardi, 2001) as there tend to be more conflict between employees and managers in such a climate, hence inviting more ethical violations (Schwepker, Ferrell, \& Ingram, 1997). As such, instrumental climate would lead to a higher propensity to engage in DB, leading to the following statement of hypothesis:

H4(b): There is a positive relationship between the weaker ethical climate type of Instrumental with the dysfunctional behaviour among the managers.

\subsubsection{Perceived Ethical Leadership (PEL)}

As employees often look outside of themselves for guidance, leaders would normally become the target of their focus (Trevino, 1986) as the tone set at the top is critical in influencing employees ethical attitude and behaviour (Trevino, Hartman, \& Brown, 2000). Perceptions of ethical leadership (PEL) describes how ethical is a leader as perceived by their subordinates as reflected through their conducts, communications, or enforcement of certain rules, resulting to such behaviours to be emulated by the followers (Brown et al., 2005). As posited by SLT, an individual would learn appropriate ways to act through a role-modeling process by observing and emulating the behaviours of credible and attractive role models, who in the context of an organization, may consist of the leaders (Bandura, 1977, 1986). Leaders may become the most potent ethics source as they hold the authority and the controlling power, including the power to reward and punish. By observing the leaders, employees would form a perception of what are the acceptable and unacceptable values and would act accordingly (Treviño, \& Brown, 2005). However, academically, the study on PEL is still at infancy (Mayer, Kuenzi, Greenbaum, Bardes, \& Salvador, 2009) with very limited empirical research (Ruiz, Ruiz, \& Martinez, 2011b).

A review on the effect of PEL on employees' unethical behaviour has almost unanimously pointed to the relationship of a negative nature (Brown et al., 2005; Ibrahim, Angelidis, \& Parsa, 2008; Mayer et al., 2009; 
Mayer et al., 2010; Neubert, Carlson, Kacmar, Roberts, \& Chonko, 2009). Leaders who engage in unethical behaviours may well be expected to create a context supporting unethical conducts, which in turn, may be observed by the employees who are more likely to imitate the inappropriate conducts (Mayer et al., 2010) and the influence would be particularly stronger if leaders are rewarded for such unethical conduct (Mayer et al., 2009; Neubert et al., 2009). Conversely, employees may be turned into highly ethical workforce if the leaders saliently exhibit and enforce practices, policies, and procedures that serve to uphold ethical conduct (Brown et al., 2005; Mayer et al., 2010; Ponnu, \& Tennakoon, 2009; Ruiz, Ruiz, \& Martinez, 2011a; Treviño, \& Brown, 2005), by ethically considering the right things to do, regularly communicating ethics with subordinates, and rewarding and punishing employees in accordance with ethical principles (Brown, \& Trevino, 2006; Hoogervorst, Cremer, \& Dijke, 2010).

Hence, DB, like manipulating performance measures, will occur more frequently in organizations whose leaders display unethical behaviours than in organizations whose leaders display more reasonable and ethical behaviour themselves (Brown et al., 2005; Brown, \& Trevino, 2006; Mayer et al., 2010; Peterson, 2004; Ponnu, \& Tennakoon, 2009; Treviño, \& Brown, 2005) as it will increase the subordinate's intention to engage in immoral behaviour (Peterson, 2004). This argument lends support to the following hypothesis:

\section{H5: Perceived ethical leadership is negatively associated with managers' propensity to engage in} dysfunctional behaviour among the managers.

\subsubsection{Personal Ethics vs Organizational Ethics}

From the discussion above, this study believes that ethics, either at the individual or organizational level, would significantly affect the occurrence of DB. Although individuals enter into an organization with their own unique personal values, Adams et al. (2001) argued that organizational values still become an overriding influence on individual moral decisions made in an organization. Individuals may be capable of quite sophisticated levels of moral reasoning, but, the influence of their superior as role models, coupled with peer expectations and the perceived consequences of behaviour, exert a powerful impact which would further influence an individual behaviour. Besides, the focus on profit as significant expected outcome, the individual economic dependence on the organization, or even the cultural beliefs, would all interact to further affect the values hold by an individual. Following this, it is argued that organizational ethics will have a stronger influence on the managers' propensity to engage in dysfunctional behaviour, leading to the last hypotheses stated as follows:

\section{H6: Organizational ethics will play a more influential role in the propensity of managers to} engage in dysfunctional behaviour as compared to personal ethics

\subsection{Theoretical Framework}

Hence, this study hypothesizes that both personal ethics (what one cognitively and affectively believes and values), and organizational ethics (values and beliefs adopted in one's social environment) would influence the commission of DB among the managers in an organization. This is because the potential for DBE to occur is a function of the definitions and cognitive learning, represented by ethical attitudes and ethical ideology, a manager might hold. Some adopt a stronger ethical stance and firmly refer to principles or rules in making a decision, while others might lower down their ethical standard and believe that the right actions should be situationally determined. The attitudes and ideologies are influenced by the ethical theory one subscribes to. A deontologist, who focuses on the consequences of their decisions or actions, would prioritize the welfare of others and believe that harming others can always be avoided, while a teleologist would weigh each situation in terms of the rightness of each individual action and hence, would embrace more of relativism ideology. However, these cognitions might inadvertently be altered so as to suit the acted behaviour, implying that at any time, behaviour is a translation of attitude or ideology into action, making them potential predictors of ethical or unethical behaviour.

However, what a manager personally believes might not suffice to influence their decision to engage in DB. This is because the managers are also expected to bow to the norms or accepted values in their environment, like the $\mathrm{COE}$, the EWC, or the ethics of their leaders so as not to be regarded as alien, or to avoid punishment. These situational factors represent the behavioural learning or differential association and differential reinforcement proposed by SLT that would subsequently influence their decision to engage in DBE. Additionally, through vicarious learning proposed by SLT, individuals in an organization will observe what others do and later imitate them (imitation).

Hence, SLT and other ethical theories, like teleology or deontology, may bridge the independent variables and the dependent variable in the following statements that may represent the underlying logic for designing and 
conducting the study. If a manager believes that (a) ethics and business should always go together (EAT), and (b) it is always important to obey rules and principles which can be universally applied (EID), then he/she would avoid from engaging in DB, so as to restore the equilibrium of the attitudes or ideology and behaviour acquired through the cognitive learning. Similarly, if a manager believes that (a) COE provides a clear guideline in conducting his/her work, (b) there is a strong EWC surrounding his/her work atmosphere, and (c) their leaders exhibit salient ethical conducts through role-modelling (PEL), then he/she would avoid DB as a result of behavioural learning. Following the discussion, the relationships between the variables can be depicted in Figure 1.

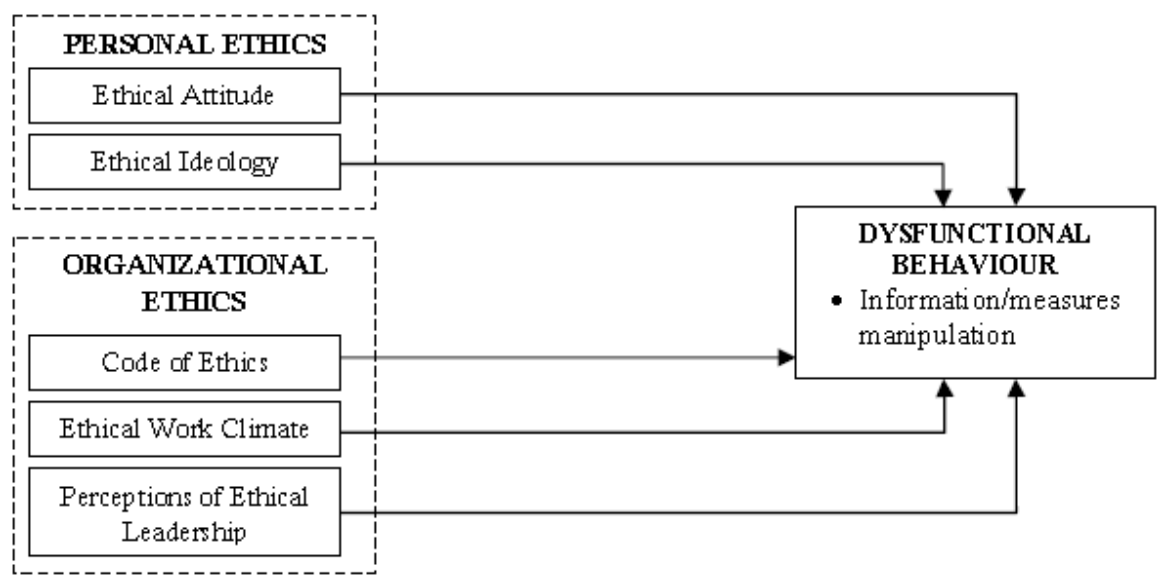

Figure 1. Ethical antecedents of dysfunctional PMCS behaviour

The above theoretical framework is derived mainly from Trevino's (1986) model of ethical decision making in organizations. The original model hypothesized that ethical decision making in organizations is explained by the interaction of individual (represented by cognitions, ego strength, field dependence, and locus of control) and situational components (immediate job context and the broader organizational culture). The proposed model originally started from the reviewing of the work done by researchers like Argyris (1953), Ridgway (1956), Hopwood (1972), Birnberg et al. (1983), Jaworski and Young (1992), Van der Stede (2000), and Soobaroyen (2007) that had sparked an interest in the issue of dysfunctional PMCS behaviour. Later, a framework proposed by Drongelen and Fisscher (2003) that relates DB to moral responsibility of the PMCS actors triggered the adaptation of Trevino's (1986) model to explain how ethics might play a crucial role in the commission of dysfunctional PMS behaviour.

\section{Conclusion and Practical Implications}

The review of literature has shown that ethics may be a strong antecedent that might influence the ethical or unethical behaviour among members in an organization, hence making it a good predictor in explaining DB in the context of PMCS. Though basically all kinds of DB can be considered as immoral, but in the case of dysfunctional PMCS behaviour, the reasons behind it might make the act as fairly moral. However, this aspect has not been given sufficient attention in the extant literature. As individuals hold certain ethical attitude and vary in their ethical ideology, they might have their own reasons whether to engage in DB or not. Similarly, organizational ethics would play a role in blending and shaping an individual employee into the ethical climate mould according to organization's prescription. Through its COE, employees would tangibly see and know the do's and the don'ts of the ethical practice expected of them, while the EWC would intangibly work its way into the culture and the process without employees even realizing it, but is strong enough to influence their ethical conduct. Of similar importance, the ethics of the respective leaders should not be underestimated as employees would normally look to their leaders for guiding their own behaviour.

Knowing the influence of ethical antecedents on dysfunctional PMCS behaviour may practically contribute some insight for the effective design and implementations of the PMCS in an organization. Hence, some precautionary steps could be taken to ameliorate the effectiveness of PMCS, hence reducing the possibility of DB. Although more and extensive studies are required to gauge the depth and spread of these DBs, it could well become an organization's priority to take into consideration the motivational and behavioural aspects of PMCS so that ethical values would not be sacrificed in the enthusiasm of the organization to become a market leader.

Besides, since unethical behaviour is proved costly to any organizations and society, understanding the relationship between different dimension of ethical climate and behaviour will enable the organizations to 
influence and take prompt actions to curb unethical behaviour (Wimbush et al., 1997). A better understanding of the dynamic nature of the employees' behaviours which might result from their personal ethics will enhance knowledge of people's behaviour in organizational settings. Hence, top management may come up with proper plans, like determining the training required to turn them into a highly ethical workforce, so as to align employees' personal ideology and attitude with the organization's interest as future interventions would be undeniably crucial to increase constructive and decrease destructive acts among employees. Similarly, an organization might benefit from the knowledge of its organizational ethics which might shed some light on which area to change, or which to enhance, so as to create a highly ethical organization as extant literatures have provided ample supports that situational factors would play a more pivotal role in influencing the behaviour of an individual as compared to one's personal values. As such, this study will bring about an interesting discovery regarding how ethics will influence dysfunctional PMCS behaviour that will add to the paucity of knowledge in this area.

\section{References}

Adams, J. S., Tashchian, A., \& Shore, T. H. (2001). Codes of ethics as signals for ethical behaviour. Journal of Business Ethics, 29, 199-211. http://dx.doi.org/10.1023/A:1026576421399

Argyris, C. (1953). Human problems with budgets. Harvard Business Review, 31(1), 97-110.

Argyris, C. (1990). The dilemma of implementing controls: The case of managerial accounting. Accounting, Organizations and Society, 15, 503-511. http://dx.doi.org/10.1016/0361-3682(90)90031-O

Bandura, A. (1977). Social Learning Theory. Englewood Cliffs, NJ: Prentice-Hall.

Bandura, A. (1986). Social foundations of thought and action. Englewood Cliffs, NJ: Prentice-Hall.

Barnett, T., Bass, K., \& Brown, G. (1994). Ethical ideology and ethical judgment regarding ethical issues in business. Journal of Business Ethics, 13, 469-480. http://dx.doi.org/10.1007/BF00881456

Barnett, T., Bass, K., Brown, G., \& Hebert, F. J. (1998). Ethical ideology and the ethical judgments of marketing professionals. Journal of Business Ethics, 17, 715-723. http://dx.doi.org/10.1023/A:1005736404300

Bass, K., Barnett, T., \& Brown, G. (1998). The moral philosophy of sales managers and its influence on ethical decision making. Journal of Personal Selling \& Sales Management, XVIII(2), 1-17.

Birnberg, J. G., Turopolec, L., \& Young, S. M. (1983). The organizational context of accounting. Accounting, Organizations and Society, 8, 111-129. http://dx.doi.org/10.1016/0361-3682(83)90018-1

Brown, M., Trevino, L. K., \& Harrison, D. A. (2005). Ethical leadership: A social learning perspective for construct development and testing. Organizational Behaviour and Human Decision Processes, 97, 117-134. http://dx.doi.org/10.1016/j.obhdp.2005.03.002

Brown, M. E., \& Trevino, L. K. (2006). Ethical leadership: A review and future directions. The Leadership Quarterly, 17, 595-616. http://dx.doi.org/10.1016/j.leaqua.2006.10.004

Brown, M. F., \& Stilwell, J. (2005, June). The ethical foundation of performance measurement and management. Public Management, 22-25.

Bruns, W., \& Merchant, K. (1990). The dangerous morality of managing earnings. Management Accounting, $72(2), 22-25$.

Courty, P., \& Marschke, G. (2008). A general test for distortion in performance measures. The Review of Economics and Statistics, 90(3), 428-441. http://dx.doi.org/10.1162/rest.90.3.428

Cullen, J. B., Victor, B., \& Stephens, C. (1989). An ethical weather report: Assessing the organization's ethical climate. Organizational Dynamics, 18, 50-62. http://dx.doi.org/10.1016/0090-2616(89)90042-9

Davis, M. A., Andersen, M. G., \& Curtis, M. B. (2001). Measuring ethical ideology in business ethics: A critical analysis of the ethics position questionnaire. Journal of Business Ethics, 32, 35-53. http://dx.doi.org/10.1023/A:1010701417165

Douglas, P. C., \& Wier, B. (2000). Integrating ethical dimensions into a model of budgetary slack creation. Journal of Business Ethics, 28, 267-277. http://dx.doi.org/10.1023/A:1006241902011

Drongelen, I. C. K.-V., \& Fisscher, O. A. M. (2003). Ethical dilemmas in performance measurement. Journal of Business Ethics, 45, 51-63. http://dx.doi.org/10.1023/A:1024120428490

Falkenberg, L., \& Herremans, I. (1995). Ethical behaviours in organizations: Directed by the formal or informal systems? Journal of Business Ethics, 14, 133-143. http://dx.doi.org/10.1007/BF00872018 
Fernando, M., Dharmage, S., \& Almeida, S. (2008). Ethical ideologies of senior Australian managers: An empirical study. Journal of Business Ethics, 82, 145-155. http://dx.doi.org/10.1007/s10551-007-9568-0

Ferrell, O. C., \& Weaver, K. M. (1978). Ethical beliefs of marketing managers. Journal of Marketing, 42, 69-73. http://dx.doi.org/10.2307/1250537

Fisher, C., \& Downes, B. (2008). Performance measurement and metric manipulation in the public sector. Business Ethics: A European Review, 17(3), 245-258. http://dx.doi.org/10.1111/j.1467-8608.2008.00534.x

Flamholtz, E. (1996). Effective organizational control: A framework, applications, and implications. European Management Journal, 14, 596-611. http://dx.doi.org/10.1016/S0263-2373(96)00056-4

Forsyth, D. R. (1992). Judging the morality of business practices: The influences of personal moral philosophies. Journal of Business Ethics, 11, 461-470. http://dx.doi.org/10.1007/BF00870557

Forsyth, D. R., \& Berger, R. E. (1982). The effects of ethical ideology on moral behaviour. The Journal of Social Psychology, 117, 53-56. http://dx.doi.org/10.1080/00224545.1982.9713406

Fritzsche, D. J. (2000). Ethical climates and the ethical dimension of decision-making. Journal of Business Ethics, 24, 125-140. http://dx.doi.org/10.1023/A:1006262914562

Ghosh, D., \& Crain, T. L. (1995). Ethical standards, attitudes toward risk, and intentional noncompliance: An experimental investigation. Journal of Business Ethics, 14, 353-365. http://dx.doi.org/10.1007/BF00872098

Greenfield, A. C. J., Norman, C. S., \& Wier, B. (2008). The effect of ethical orientation and professional commitment on earnings management behaviour. Journal of Bussiness Ethics, 83, 419-434. http://dx.doi.org/10.1007/s10551-007-9629-4

Gupta, J. L., \& Sulaiman, M. (1996). Ethical orientations of managers in Malaysia. Journal of Business Ethics, 15, 735-748. http://dx.doi.org/10.1007/BF00381738

Harell, A., \& Harrison, P. (1994). An incentive to shirk, privately-held information and managers' project evaluation decisions. Accounting, Organizations and Society, 19, 569-577. http://dx.doi.org/10.1016/0361-3682(94)90024-8

Helin, S., \& Sandstrom, J. (2007). An inquiry into the study of corporate codes of ethics. Journal of Business Ethics, 75, 253-271. http://dx.doi.org/10.1007/s10551-006-9251-x

Henle, C. A., Giacalone, R. A., \& Jurkiewicz, C. L. (2005). The role of ethical ideology in workplace deviance. Journal of Business Ethics, 56, 219-230. http://dx.doi.org/10.1007/s10551-004-2779-8

Hirst, M. K. (1981). Accounting information and the evaluation of subordinate performance: A situational approach. The Accounting Review, LVI(4), 771-784.

Hirst, M. K. (1983). Reliance on accounting performance measures, task uncertainty and dysfunctional behaviour: Some extensions. Journal of Accounting Research, 21, 596-605. http://dx.doi.org/10.2307/2490793

Hoogervorst, N., Cremer, D. D., \& Dijke, M. V. (2010). Why leaders not always dissaprove of unethical follower behaviour: It depends on the leader's self-interest and accountability. Journal of Business Ethics, 95, 29-41. http://dx.doi.org/10.1007/s10551-011-0793-1

Hopwood, A. G. (1972). An empirical study of the role of accounting data in performance evaluation. Journal of Accounting Research, 10, S156-S182. http://dx.doi.org/10.2307/2489870

Ibrahim, N. A., Angelidis, J. P., \& Parsa, F. (2008). Business ethics: Past observations, current trends and future prospects. Review of Business Research, 8(5), 78-88.

Izraeli, D. (1988). Ethical beliefs and behavior among managers: A cross-cultural perspective. Journal of Business Ethics, 7, 263-271. http://dx.doi.org/10.1007/BF00381831

Jaworski, B. J., \& Young, S. M. (1992). Dysfunctional behaviour and management control: An empirical study of marketing managers. Accounting, Organizations and Society, 17(1), 17-35. http://dx.doi.org/10.1016/0361-3682(92)90034-P

Jennings, M. M. (2006). Business ethics: Case studies and selected readings (5th ed.). Mason: Thomson South-Western.

Kantor, J., \& Weisberg, J. (2002). Ethical attitudes and ethical behaviour: are managers role models? International Journal of Manpower, 23(8), 687-703. http://dx.doi.org/10.1108/01437720210453885 
Kaptein, M. (2011). Toward effective codes: Testing the relationship with unethical behaviour. Journal of Business Ethics, 99, 233-251. http://dx.doi.org/10.1007/s10551-010-0652-5

Keasey, K., Moon, P., \& Duxbury, D. (2000). Performance measurement and the use of league tables: some experimental evidence of dysfunctional consequences. Accounting and Business Research, 30(4), 275-286. http://dx.doi.org/10.1080/00014788.2000.9728945

Kish-Gephart, J. J., Harrison, D. A., \& Trevino, L. K. (2010). Bad apples, bad cases and bad barrels: Meta-analytic evidence about sources of unethical decisions at work. Journal of Applied Psychology, 95, 1-31. http://dx.doi.org/10.1037/a0017103

KPMG. (2010). KPMG Malaysia Fraud Survey Report 2009. Kuala Lumpur: KPMG.

Lau, C. M. (1999). The effect of emphasis on tight budget targets and cost control on production and marketing managers' propensity to create slack. British Accounting Review, 31, 415-437. http://dx.doi.org/10.1006/bare.1999.0113

Longenecker, J. G., McKinney, J. A., \& Moore, C. W. (2003). Ethical attitudes of founders and other entrepreneurs. Paper presented at the USASBE 17th Annual National Conference: South Carolina, 23-26 January $2003 . \quad$ Retrieved from http://usasbe.org/knowledge/proceedings/proceedingsDocs/USASBE2003proceedings-17.pdf

Longenecker, J. G., Moore, C. W., Petty, J. W., Palich, L. E., \& McKinney, J. A. (2006). Ethical attitudes in small businesses and large corporations: Theory and empirical findings from a tracking study spanning three decades. Journal of Small Business Management, 44(2), 167-183. http://dx.doi.org/10.1111/j.1540-627X.2006.00162.x

Marques, P. A., \& Azevedo-Pereira, J. (2009). Ethical ideology and ethical judgments in the Portuguese accounting profession. Journal of Business Ethics, 86, 227-242. http://dx.doi.org/10.1007/s10551-008-9845-6

Martin, K., \& Cullen, J. B. (2006). Continuities and extensions of ethical climate theory: A meta-analytic review. Journal of Business Ethics, 69, 175-194. http://dx.doi.org/10.1007/s10551-006-9084-7

Martinez, V. (2005). What is the value of using PMS? Perspectives on Performance, 4(2), 16-18.

Mayer, D., Kuenzi, M., Greenbaum, R., Bardes, M., \& Salvador, R. (2009). How low does thical leadership flow? Test of a trickle down model. Organizational Behaviour and Human Decision Processes, 108(1), 1-13. http://dx.doi.org/10.1016/j.obhdp.2008.04.002

Mayer, D. M., Kuenzi, M., \& Greenbaum, R. L. (2010). Examining the link between ethical leadership and employee misconduct: The mediating role of ethical climate. Journal of Business Ethics, 95, 7-16. http://dx.doi.org/10.1007/s10551-011-0794-0

Medlin, B., \& Green, K. W. J. (2003). Ethics in small business: Attitudes and perceptions of owners/managers. Academy of Entrepreneurship Journal, Jan-July. Retrieved from http://findarticles.com/p/articles/mi_hb6005/is_1_2_9/ai_n29064704/

Merchant, K. A. (1990). The effects of financial controls on data manipulation and management myopia. Accounting, Organizations and Society, 15(4), 297-313. http://dx.doi.org/10.1016/0361-3682(90)90021-L

Millar, M. G., \& Millar, K. (1997). Effects of situational variables on judgments about deception and detection $\begin{array}{llll}\text { accuracy. Basic and Applied Social Psychology, 19, 401-410. } & \text {. }\end{array}$ http://dx.doi.org/10.1207/s15324834basp1904_1

Mitchelli, V.-W., \& Chan, J. K. L. (2002). Investigating UK consumers' unethical attitudes and behaviours. Journal of Marketing Management, 18, 5-26. http://dx.doi.org/10.1362/0267257022775873

Nanni, A. J., Dixon, J. R., \& Vollman, T. E. (1990). Strategic control and performance measurement. Journal of Cost Management, Summer, 33-42.

Neubert, M. J., Carlson, D. S., Kacmar, K. M., Roberts, J. A., \& Chonko, L. B. (2009). The virtuous influence of ethical leadership behaviour: Evidence from the field. Journal of Business Ethics, 90, 157-170. http://dx.doi.org/10.1007/s10551-009-0037-9

Okpara, J. O. (2003). Can corporate ethical codes of conduct influence behavior? An exploratory study of financial managers in a developing economy. Paper presented at the Academy of Business \& Administrative Sciences (ABAS) XI International Conference: Brussels, Belgium., 
Onsi, M. (1973). Factor analysis of behavioural variables affecting budgetary slack. The Accounting Review, July, 535-548.

Otley, D. T. (1978). Budget use and managerial performance. Journal of Accounting Research, 16, $122-149$. http://dx.doi.org/10.2307/2490414

Otley, D. T. (1999). Performance management: A framework for management control systems research. Management Accounting Research, 10(4), 363-382. http://dx.doi.org/10.1006/mare.1999.0115

Peterson, D. (2004). Perceived leader integrity and ethical intentions of subordinates. The Leadership \& Organization Development Journal, 25(1), 7-23. http://dx.doi.org/10.1108/01437730410512741

Peterson, D. K. (2002a). The relationship between unethical behaviour and the dimensions of the ethical climate questionnaire. Journal of Business Ethics, 41, 313-326. http://dx.doi.org/10.1023/A:1021243117958

Peterson, D. K. (2002b). Deviant workplace behavior and the organization's ethical climate. Journal of Business and Psychology, 17, 47-61. http://dx.doi.org/10.1023/A:1016296116093

Ponnu, C. H., \& Tennakoon, G. (2009). The association between ethical leadership and employee outcomes-the Malaysian case. Electronic Journal of Business Ethics and Organization Studies, 14(1), 21-31.

Pricewaterhouse Coopers. (2009). The global economic crime survey: Economic crime in a downturn. London: Pricewaterhouse Coopers.

Reckers, P. M. J., Sanders, D. L., \& Roark, S. J. (1994). The influence of ethical attitudes on taxpayer compliance. National Tax Journal, 47(4), 825-836.

Ridgway, V. F. (1956). Dysfunctional consequences of performance measurement. Administrative Science Quarterly, 1(2), 240-247. http://dx.doi.org/10.2307/2390989

Rudolph, F. M. (2006). Cognitive dissonance: General experimental psychology cognitive dissonance lab. Frederick M. Rudolph ${ }^{1}$. page on Social Psychology. Retrieved from http://www.ithaca.edu/faculty/stephens/cdback.html

Ruiz, P., Ruiz, C., \& Martinez, R. (2011a). The cascading effect of top management's ethical leadership: Supervisors or other lower-hierarchical level individuals? African Journal of Business Management, 5(12), 4755-4764.

Ruiz, P., Ruiz, C., \& Martinez, R. (2011b). Improving the "Leader-Follower" relationship: Top manager or supervisor? The thical leadership trickle-down effect on follower job response. Journal of Business Ethics, 99, 587-608. http://dx.doi.org/10.1007/s10551-010-0670-3

Schwartz, M. S. (2001). The nature of the relationship between corporate codes of ethics and behaviour. Journal of Business Ethics, 32, 247-262. http://dx.doi.org/10.1023/A:1010787607771

Schweitzer, M. E., Ordonez, L., \& Douma, B. (2004). Goal setting as a motivator of unethical behaviour. Academy of Management Journal, 47(3), 422-432. http://dx.doi.org/10.2307/20159591

Schwepker, C. H. J., Ferrell, O. C., \& Ingram, T. N. (1997). The influence of ethical climate and ethical conflict on role stress in the sales force. Journal of the Academy of Marketing Science, 25, 99-108. http://dx.doi.org/10.1007/BF02894345

Simons, R. (1995). Control in an age of empowerment. Harvard Business Review, 67(2), 80-88.

Somers, J. M. (2001). Ethical codes of conduct and organizational context: A study of the relationship between codes of conduct, employee behavior and organizational values. Journal of Business Ethics, 30, 185-195. http://dx.doi.org/10.1023/A:1006457810654

Soobaroyen, T. (2007). Management control systems and manager dysfunctional behaviour: An empirical study of direct, intervening and moderating effects. Unpublished Doctoral Thesis, The University of Wales, Aberystwyth, UK.

Stevens, B. (1994). An analysis of corporate ethical code studies: "Where do we go from here?". Journal of Business Ethics, 13, 63-69. http://dx.doi.org/10.1007/BF00877156

Tang, T. L.-P., Chen, Y.-J., \& Sutarso, T. (2008). Bad apples in bad (business) barrels-The love of money, machiavellianism, risk tolerence and unethical behaviour. Management Decision, 46(2), $243-263$. http://dx.doi.org/10.1108/00251740810854140

Trevino, L. K. (1986). Ethical decision making in organizations: A person-situation interactionist model. 
Academy of Management Review, 11, 601-617.

Treviño, L. K., \& Brown, M. E. (2005). The Role of Leaders in Influencing Unethical Behavior in the Workplace. In R. E. Kidwell, \& C. L. Martin (Eds.), Managing Organizational Deviance (pp. 69-87). Thousand Oaks, CA: Sage Publications. http://dx.doi.org/10.4135/9781452231105.n3

Trevino, L. K., Hartman, L. P., \& Brown, M. (2000). Moral person and moral manager: How executives develop a reputation for ethical leadership. California Management Review, 42(4), 128-142. http://dx.doi.org/10.2307/41166057

Trevino, L. K., \& Nelson, K. E. (2004). Managing Business Ethics: Straight talk about how to do it right (3rd ed.). Danvers: John Wiley \& Sons.

Vakkuri, J., \& Meklin, P. (2006). Ambiguity in performance measurement: A theoretical approach to organizational uses of performance measurement. Financial Accountability \& Management, 22(3), 0267-4424.

Valentine, S., \& Barnett, T. (2002). Ethics codes and sales professionals perceptions of their organizations ethical values. Journal of Business Ethics, 40(3), 191-200. http://dx.doi.org/10.1023/A:1020574217618

Van der Stede, W. A. (2000). The relationship between two consequences of budgetary controls: budgetary slack creation and managerial short-term orientation. Accounting, Organizations and Society, 25, 609-622. http://dx.doi.org/10.1016/S0361-3682(99)00058-6

Vardi, Y. (2001). The effects of organizational and ethical climates on misconduct at work. Journal of Business Ethics, 29, 325-337. http://dx.doi.org/10.1023/A:1010710022834

Velasquez, M. G. (2006). Business Ethics: Concepts and Cases (6th ed.). Upper Sadle River: Pearson International.

Victor, B., \& Cullen, J. B. (1987). A theory and measure of ethical climate in organizations. In W. C. Frederick (Ed.), Research in Corporate Social Performance and Policy (pp. 51-71). Greenwich, CT: JAI Press.

Victor, B., \& Cullen, J. B. (1988). The organizational bases of ethical work climates. Administrative Science Quarterly, 33, 101-125. http://dx.doi.org/10.2307/2392857

Waggoner, D. B., Neely, A. D., \& Kennerly, M. P. (1999). The forces that shape organizational performance measurement systems: An interdisciplinary review. International Journal of Production Economics, 60-61, 53-60. http://dx.doi.org/10.1016/S0925-5273(98)00201-1

Weber, J., \& Gillespie, J. (1998). Differences in ethical beliefs, intentions, and behaviours. Business and Society, 37(4), 447-466. http://dx.doi.org/10.1177/000765039803700406

Wells, J. T. (2001). Why employees commit fraud. Journal of Accountancy, February. Retrieved from http://www.journalofaccountancy.com/

Wimbush, J. C., \& Shepard, J. M. (1994). Toward an understanding of ethical climate: Its relationship to ethical behaviour and supervisory influence. Journal of Business Ethics, 13, 637-647. http://dx.doi.org/10.1007/BF00871811

Wimbush, J. C., Shepard, J. M., \& Markham, S. E. (1997). An empirical examination of the relationship between ethical climate and ethical behaviour from multiple levels of analysis. Journal of Business Ethics, 16, 1705-1716. http://dx.doi.org/10.1023/A:1017952221572

Wong, H. M. (2008). Religiousness, love of money, and ethical attitudes of Malaysian Evangelical Christians in business. Journal of Business Ethics, 81, 169-191. http://dx.doi.org/10.1007/s10551-007-9487-0

Zabid, A. R. M., \& Alsagoff, S. K. (1993). Perceived ethical values of Malaysian managers. Journal of Business Ethics, 12, 331-337. http://dx.doi.org/10.1007/BF01666537 